\title{
Beta-2 Microglobulin Greater than 5.5 $\mathrm{g} / \mathrm{mL}$
}

National Cancer Institute

\section{Source}

National Cancer Institute. Beta-2 Microglobulin Greater than $5.5 \mathrm{~g} / \mathrm{mL}$. NCI Thesaurus.

Code C95147.

A laboratory test result indicating the presence of high levels of beta- 2 microglobulin in blood or urine, exceeding $5.5 \mathrm{~g} / \mathrm{mL}$. 